\title{
Qualities Evaluation of Extruded Ready to Eat Snack from Composite Non-Wheat Flours
}

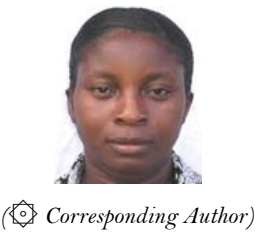

\author{
Olabinjo, Oyebola Odunayo ${ }^{10}$ \\ Olumurewa, John Alaba Victor ${ }^{2}$
}

'Department of Agricultural and Environmental Engineering, Federal University of Technology, Akure, Nigeria.

Email:oyebolabinjo@gmail.com Tel: +2348039561512

${ }^{2}$ Department of Food Science and Technology, Federal University of Technology, Akure, Nigeria. Email:jav_murewa@yahoo.com Tel: +2348062966602

\begin{abstract}
Ready-to-eat flakes are processed grain formulations suitable for human consumption without further cooking in the home. Ready-to-eat flakes was produced from the mixtures of yellow maize, defatted soybean, defatted groundnut, moringa seed, scent leaf, pepper, salt and gray fish using extrusion technology at five different proportions of the ingredients. The proximate, minerals, antioxidant, functional properties, cracking strength and sensory properties of the formulations were investigated using standard methods. The research established that the use of local cereal based for the production of flakes is possible and good when using extrusion technology. The extruded products provide good quality flakes when supplemented maize with soybean and groundnut. It was deduced from the chemical composition of the flakes, that blending of cereals and legumes cause a significant increase in protein and carbohydrate contents making it a suitable ingredient for controlling malnutrition in diets. With respect to the nutritional composition, the addition of moringa seed to the blend samples increased the potassium, calcium, iron and phosphorus content of the flakes; this makes the blends better source of micronutrients. Also, the incorporating of moringa seed increased the total phenolic compound, vitamin $\mathrm{C}$ and flavonoids content. The samples from composite flour had the ability to withstand cracking strength compare to $100 \%$ wheat flour.
\end{abstract}

ABSTRACT

Keywords: Flakes, Nutritional characteristics, Maize, Defatted soybean, Defatted groundnut, Moringa seed.

DOI: $10.20448 / 808.5 .1 .14 .24$

Citation | Olabinjo, Oyebola Odunayo; Olumurewa, John Alaba Victor (2020). Qualities Evaluation of Extruded Ready to Eat Snack from Composite Non-Wheat Flours. Scientific Modelling and Research, 5(1): 14-24.

Copyright: This work is licensed under a Creative Commons Attribution 3.0 License

Funding: This study received no specific financial support.

Competing Interests: The authors declare that they have no competing interests.

History: Received: 4 November 2019/ Revised: 9 December 2019/ Accepted: 14 January 2020/ Published: 20 February 2020

Publisher: Online Science Publishing 


\section{Highlights of this paper}

- Local blended flakes as ready to eat flakes.

- Local blended flakes with Cereals and Legumes are better source of micronutrients.

- Local blended flakes could be used as a means of preventing malnutrition among infants and aged people in rural communities.

\section{INTRODUCTION}

Ready-to-eat flakes are processed grain formulations suitable for human consumption without further cooking in the home. They are relatively shelf-stable, light weight, and convenient to ship and store. Flakes by definition are breakfast cereal that use coarsely ground flour to invent ready-to-eat chips such as graham cracker. Ready-to-eat cereals (RTEC) are defined as finished product cereals that can be taken without further preparation and are also known as cold cereals. RTEC are high in fibre foods with modified vitamins and minerals including vitamins B, iron and calcium. Moreover, consumption of RTEF has also been associated with a greater likelihood of having vitamin and mineral intakes above recommended daily requirements, especially for calcium [1]. Cereals have been used over the years as industrial raw material based on the fibre, carbohydrate, low fat and protein content. Cereals include maize and sorghum which are enriched in minerals such as sulphur containing essential amino acid such as methionine, cysteine and tryptophan. Legumes and oil seeds are relatively low in sulphur containing amino acids, but very high in another essential amino acid like, lysine as reported by Kanu, et al. [2]. In recent times food researchers and processors have integrated legumes into natural cereal formulations as nutrient diversification scheme as well as exploits to reduce the incidence of malnutrition among vulnerable groups. Cereals can be appended with most oil seeds and legumes that are rich in essential amino acids particularly the Sulphur enriched ones [3]. Thus, appended cereal food will improve the nutritional and chemical value of the resulting fortified food compared to the individual components. Moringa (Moringa oleifera) is one of the indigenous vegetables that is widely consumed and used for its health benefits. Through research, underutilized moringa seeds contain significant minerals (calcium, phosphorus and iron), vitamins (A, B and C) amino acids, vitamins and carotene. Moringa seeds has some high considerable medicinal uses with high nutritional value, minerals, and are a good source of protein, vitamins, beta-carotene, amino acids and various phenolic [4].

It was reported by Gopalakrishnan, et al. [5] that moringa seed has a significant higher content of protein, fat and mineral (especially magnesium) than moringa leaves. It was based on this fact that Moringa seed had been used for combatting malnutrition in infant and nursing mothers. There is a possibility of employing the starch components derived from cereal grains and the protein, functional property and dietary fibre components from legumes to create a healthy, nutritious and disease resistant food for consumers.

In Nigeria, the high cost of commercial industrially produced high protein energy rich breakfast products make them out of reach to low income earners, consequently people in this wage category who constitute an appreciable percentage of the population depend for their breakfast on left over super or at best on sole cereal porridge that is of low nutritional value. There is therefore the need to develop affordable low cost high protein energy breakfast product whose production would not require high technology [6]. Hence, the need for immingling legumes with cereals in finished food development [7]. The presence of legumes and grains provide more valuable and cheaper protein that contains all essential amino acids in right proportion because their amino acid complements each other [8-11]. However, the practice of producing a ready to eat flakes from blends of maize, soybean and groundnut is an efficient means of meliorating the nutritional composition of ready to eat flakes. Enhancing the use of underutilized seed for food and snacks production is one of the meliorate ways to reduce malnutrition, environmental and financial vulnerability [12]. Therefore, it is of interest to process moringa seeds into acceptable, ready-to-eat and 
safe products together with other locally available materials including maize, defatted soybean and defatted groundnut flour.

\section{MATERIALS AND METHODS}

\subsection{Materials}

Defatted ground nut, maize, soybeans, moringa seed, and other ingredients to be used for this study will be purchased from Sabo market in Ilesha. The flaking will be carried out with a table top extruder machine available at Famex Zero Waste Farm, Ilesha, Osun State. Analyses of the raw materials and the produced flakes will be carried out at Federal university of Technology Food Science Laboratory, Akure, Ondo State, Nigeria.

\subsection{Sample Preparation and Storage}

Soybeans, groundnut, maize and moringa seeds used was properly cleaned and sorted to remove stones, dirt, chaff, weevil seeds and other extraneous matters. The modification method described by Ndife, et al. [13] was used to processing of maize grains into flour. Matured moringa seeds were manually removed from the seed kernels and dried using cabinet drier at $60^{\circ} \mathrm{C}$ for 5 days. The dried moringa seeds were milled in a clean Marlex blender and sieved using a sieve of $500 \mathrm{~mm}$ mesh size, to obtain a fine powder. Groundnut seed was roasted at the temperature of $120^{\circ} \mathrm{C}$ for 30 minutes, dehulled to remove the shell, dry milled, screw pressed, pulverized and sundry for 72 hours. Soy flour was prepared according to the method described by AOAC [14]. Soybeans were roasted, decorticated, winnowed and milled into fie flour using hammer mill (model EU 5000 D) and sieved through $250 \mu \mathrm{m}$ aperture sieve. The four prepared flours were mixed with other spices and condiment in varying proportions to obtain four different samples Table 1. The samples were stored in an air tight environment and kept away from moisture.

Table-1. Composite Flour Formulations for ready-to-eat flakes made from Blends sample.

\begin{tabular}{lcccc}
\hline Sample code & $\mathbf{4 2 5}$ & $\mathbf{5 2 2}$ & $\mathbf{7 1 1}$ & $\mathbf{8 2 1}$ \\
\hline Ingredient & $\mathrm{A}(\%)$ & $\mathrm{B}(\%)$ & $\mathrm{C}(\%)$ & $\mathrm{D}(\%)$ \\
Maize & 35 & 35 & 35 & 35 \\
Defatted soybean & 30 & 25 & 20 & 10 \\
Defatted Groundnut & 10 & 15 & 20 & 30 \\
Moringa seed & 5 & 5 & 5 & 5 \\
Scent leaf & 5 & 5 & 5 & 5 \\
Blended cray fish & 5 & 5 & 5 & 5 \\
Blended ginger & 5 & 5 & 3 & 5 \\
Pepper & 3 & 3 & 2 & 3 \\
Salt & 2 & 2 & 2 \\
\hline
\end{tabular}

\subsection{Determination of Nutritional Composition and Ascorbic acid (Vitamin C)}

The nutrient compositions and Ascorbic acid of the samples was analyzed using standard method of AOAC [14]. The Proximate parameters analyzed were; moisture content, ash, crude fiber, crude protein crude fat, carbohydrate and Ascorbic acid. The experiment was carried out in quadruplicate on each of mixes using standard methods. 


\subsection{Antioxidants}

a. Determination of Flavonoid

The flavonoid content of the sample was determined according to the procedure of Boham and Kocipai [15]. The filtrate was later transferred into crucible and evaporated into dryness in a water bath and weighted to a constant weight and determined using Equation 1.

$$
\text { Percentage flavonoid }(\%)=\frac{\text { intial weight-final weight of the sample }}{\text { intial weight }} \times \frac{100}{1}
$$

\section{b. Determination of Total Phenol}

The total phenolic content of the sample was analyzed using Folin-ciocalteu assay [16] using gallic acid as the standard. The mixture of the sample was mixed with distilled water to make a solution, 3 ml of Folin-ciocalteu reagents solution, and $7 \%$ of the mixture was vortexed and incubated for 8 minutes at room temperature. The mixture was allowed to stand for 2 hours at room temperature. The absorbance was measured at $765 \mathrm{~mm}$ against distilled water as blank. The total phenolic content was expressed as $\mathrm{mg} / \mathrm{L}$ gallic acid equivalent (GAE).

\subsection{Functional Properties Determination \\ a. Bulk Density Determination}

Bulk density was analyzed for each of the formulated samples using the method described by Onwuka [17]. Bulk density was estimated as mass per unit volume of the sample $(\mathrm{g} / \mathrm{ml})$.

\section{b. Determination of Water Holding Capacity}

The Water and Fat absorption capacities of the formulated samples were analyzed using the method described by Onwuka [17]. The absorption capacity was expressed as gram of oil or water absorbed (or retained) per gram of sample.

\section{c. Determination of Swelling Capacity}

The swelling capacity was analyzed by the method described by Sanni, et al. [18] for 10mins,30mins, 60mins and $240 \mathrm{mins}$.

\section{d. Determination of Gelation Concentration}

The least gelation concentration (LGC) was evaluated using of Coffmann and Garciaj [19] as modified by Adeleke and Odedeji [20]. The flour dispersions of $2,4,6,8,10,12,14,16,18,20,22$, and 30\% (w/v) prepared in 5 $\mathrm{ml}$ distilled water and heated at $90{ }^{\circ} \mathrm{C}$ for $1 \mathrm{~h}$ in water bath. The contents were cooled under tap water and kept for $2 \mathrm{~h}$ at $10 \pm 2{ }^{\circ} \mathrm{C}$. The least gelation concentration was determined as that concentration when the sample from inverted tube did not slip.

\section{e. Determination of Mineral Content}

The mineral contents of the formulated samples were analysed using [14]. Using dry ashing, the sample was ashed at $550^{\circ} \mathrm{C}$ for $3 \mathrm{~h} .5 \mathrm{ml}$ of $6 \mathrm{~N}$ hydrochloric acid $(\mathrm{HCl})$ was mixed with the ash and made up to $50 \mathrm{ml}$ with distilled water. Selected minerals analyzed were; iron (Fe), calcium (Ca), magnesium (Mg), sodium (Na), manganese, copper $(\mathrm{Cu})$, phosphorus $(\mathrm{P})$ and zinc $(\mathrm{Zn})$ were determined by atomic absorption spectrophotometer. (Buck Scientific Atomic Absorption Emission Spectrophotometer model 205, manufactured by Nowalk, Connecticut, USA) using standard wavelengths. 


\subsection{Sensory Evaluation}

The four formulated samples were served to 20 semi-trained panelists consisting of students of the Department of Food Science and Technology, Federal University of Technology, Akure. Panelist were chosen on the basis of their willingness and commitment to partake in the sensory evaluation, using a 9-point Hedonic scale (1- dislike extremely, 9- like extremely). The samples were served to assessed for appearance, consistency, flavor, taste, aftertaste, mouth feel, and overall acceptability.

\subsection{Statistical Analysis}

The sensory scores obtained were further subjected to a one-way Analysis of Variance (ANOVA). The Least Significant Difference (LSD) test and Duncan Multiple Range Tests were used to determine significant differences between means and separate means respectively at $\mathrm{p}<0.05$ levels using SPSS package version 21 .0.

\section{RESULTS AND DISCUSSION}

\subsection{Proximate Composition of the Blends Samples}

The protein content of the flakes from composite flour decrease with decrease soybean flour substitution in the mixes. Protein content of the flakes ranged from $18.44 \%$ to $21.69 \%$ Table 2 . The protein content of the four formulations were significantly different $(\mathrm{p}<0.05)$ from each other. Among the composite flours, composite flour with $10 \%$ soybean and $30 \%$ groundnut flour substitution had the highest protein content (21.69\%) while the lowest value (18.44\%) was observed in sample 711 (20\% soybean and 20\% groundnut). These values are higher than other related previous studies; lower values were recorded for the commercial control sample, Weetabix Original (11.50\%), a breakfast meal containing African yam bean, maize, sorghum and soybean (13.53-15.02\%) by Agunbiade and Ojezele [21] as well as breakfast cereal made from treated pigeon pea and sorghum (17.22 \%) by Mbaeyi [22] respectively. The high protein content of the products may be assigned to the presence of defatted groundnut flour used in the formulations. Raw groundnut has been reported to contain about 48\% protein [23]. The progressive solubilization and leaching out of the nitrogenous substances during soaking and boiling of the legume may be responsible for the slight protein reduction in the samples [24] other than these. The generally high level of protein, however demonstrates the effect of supplementing legumes in ready-to-eat flakes. High crude protein of the soy-maize-groundnut.

Table-2. Proximate analysis of ready-to-eat flakes from blends (Dry Basis).

\begin{tabular}{|c|c|c|c|c|c|}
\hline Samples & Fibre (\%) & Fat (\%) & Ash (\%) & Protein (\%) & Carbohydrate (\%) \\
\hline 425 & $7.43 \pm 0.12^{\mathrm{d}}$ & $9.95 \pm 0.20^{\mathrm{d}}$ & $7.47 \pm 0.45^{\mathrm{d}}$ & $20.38 \pm 0.06^{b}$ & $54.25 \pm 0.29^{\mathrm{a}}$ \\
\hline 522 & $12.36 \pm 0.12^{\mathrm{a}}$ & $13.89 \pm 0.32^{b}$ & $7.35 \pm 0.06^{\mathrm{a}}$ & $18.68 \pm 0.07^{\mathrm{d}}$ & $46.49 \pm 0.42^{b}$ \\
\hline 711 & $8.79 \pm 0.25^{\mathrm{c}}$ & $14.58 \pm 0.00^{\mathrm{a}}$ & $6.14 \pm 0.06^{\mathrm{c}}$ & $18.44 \pm 0.02^{c}$ & $52.02 \pm 0.22^{\mathrm{c}}$ \\
\hline 821 & $10.18 \pm 0.12^{b}$ & $11.90 \pm 0.00^{\mathrm{c}}$ & $6.01 \pm 0.12 \mathrm{~b}^{\mathrm{c}}$ & $21.69 \pm 0.00^{\mathrm{a}}$ & $46.42 \pm 0.31^{\mathrm{d}}$ \\
\hline
\end{tabular}

Note: Values are means + SD of triplicate determinations Means differently superscripted along the vertical columns are significantly different $(\mathrm{p}<0.05)$.

Composite flour signifies that the composite flour can serve as cheap source of protein to African Populace Fat content of the flakes from composite flour ranged from $9.95 \%$ to $14.58 \%$. Among the five samples, flakes with $20 \%$ soybean and 20\%groundnut flour blend had the highest fat content $(14.58 \%)$ while the lowest value $(9.95 \%)$ was observed in soybean: groundnut blend flour with 30:10 respectively. Fat content ware significantly different $(\mathrm{p}<$ 0.05) for all the formulations. The fat content of the flour was relatively high because it was reported that raw soybean and raw groundnut has a fat content of $40 \%$ and $36-54 \%$ respectively [23] which was used for the 
mixtures. The fat content of the biscuit made from Sorghum and Pigeon pea composite flour range from 8.70$14.2 \%$ [19] which is in line with this study. Most of the legumes, with the exception of groundnuts and soybeans contain less than $3 \%$ fat [25]. Higher fat values were recorded for fortified breakfast cereals made from African yam beans, maize, sorghum and soybean as 3.7\% [21]. The results of the ash content analysis of the formulated samples showed significant differences $(\mathrm{p}<0.05)$ with values ranging from 2.37 to $7.47 \%$. Malted soy-sorghum biscuit was recorded to have $3.14 \%$ by Bolarinwa, et al. [26] Lower values, 1.36\% [21] and $1.50 \%$ [20] were recorded by other researchers. The high ash values recorded in this study may be attributed to the presence of defatted soybean and whole maize grains used as part of the ingredients in this study.

The values obtained from the findings of crude fiber content of the formulated breakfast cereals ranged from 7.43\% to $12.36 \%$. Lower values, $3.1-3.8 \%$ [18] and 1.54-4.0\% [20] were previously recorded for other ready-to-eat cereals formulation. The control sample- Weetabix however contained a fiber value of $10 \%$. Fiber is needed to aid in digestion and keep the gastrointestinal tract healthy and also keep the blood sugar stable. It slows down the release of glucose during digestion, so cells require less insulin to absorb that glucose. The American Diabetes Association recommends that people with diabetes should consume 25-50g of fiber per day [27]. The fecal bulking action of insoluble fiber makes it useful in the treatment of constipation and diverticular disease [28]. The values from the carbohydrate content analysis of the formulated samples ranged from 46.42 to $54.25 \%$ with all the samples showing significantly different $(\mathrm{p}<0.05)$. Flakes with formulation 30:10 (soybean: groundnut) respectively had the highest carbohydrate value of $54.25 \%$ and lowest value $46.42 \%$ for $10: 30$ soybean and groundnut blends respectively. Higher carbohydrate values were reported for breakfast cereals formulated from sorghum and pigeon pea [20] as well as the control- Weetabix (68.4\%) [29]. The higher carbohydrate values recorded by other researchers may be assigned to the high content of the cereals and legumes used as the main ingredients in the formulations [2].

\subsection{Functional Properties}

The result of evaluation of the functional properties of the developed flakes is shown in Table 3. The highest bulk density was observed for samples $821(10 \%$ defatted soybean and $30 \%$ defatted groundnut flour $)(0.80 \mathrm{~g} / \mathrm{ml})$ and lowest for sample 522 (25\% defatted soybean and $15 \%$ defatted groundnut flour) $(0.58 \mathrm{~g} / \mathrm{ml})$. The variation in bulk density could be as a result of the variation in starch content. Iwe and Onalope [30] reported that starch content increased bulk density. Bulk density mediates the relative volume of packaging material required for the product. The higher the bulk density, the denser the packaging material required. It also designates the porosity of a product which influences the package design and could be used in determining the type of packaging material required [30] Swelling capacity of flours is a function of the size of particles, varieties and processing methods or unit operations. High swelling capacity was reported as one of the main criteria of a good product [31]. The value of swelling capacity recorded for composite flour for sample $711(109.69 \mathrm{ml})$ had the highest and lowest for sample 100 (65.96 $\mathrm{ml})$. The results of swelling capacity for all the samples was above average this implied the samples were of good quality. There was significant difference $(\mathrm{P}<0.05)$ in the swelling capacity of all the samples studied.

Water absorption capacity (WAC) denotes the extent to which protein can be incorporated into food formulation. High water absorption capacity value implies increase in digestibility of the starch. The water absorption capacity values of the composite flour ranged from $668.31 \%$ to $87.97 \%$. Sample 425 recorded the highest water absorption capacity (668.31\%) and sample 100 recorded the lowest water absorption capacity (87.97\%). 
Table-3. Functional analysis of composite flour.

\begin{tabular}{|c|c|c|c|c|c|}
\hline Samples & $\begin{array}{c}\text { Bulk } \\
\text { Density }(g / m l)\end{array}$ & $\begin{array}{c}\text { Water } \\
\text { Absorption }(\mathrm{g} / \mathrm{ml})\end{array}$ & $\begin{array}{c}\text { Swelling } \\
\text { Capacity }(\mathrm{ml})\end{array}$ & $\begin{array}{c}\text { Disperse Capacity } \\
(\%)\end{array}$ & $\begin{array}{c}\text { Gelation } \\
\text { Cont }(\mathrm{g} / \mathrm{ml})\end{array}$ \\
\hline 425 & $0.72 \pm 0.20^{\mathrm{a}}$ & $659.49 \pm 6.52^{\mathrm{a}}$ & $89.71 \pm 0.20^{\mathrm{c}}$ & $89.91 \pm 0.20^{c}$ & 14 \\
\hline 522 & $0.58 \pm 0.15^{\mathrm{a}}$ & $658.51 \pm 10.00^{\mathrm{a}}$ & $90.20 \pm 0.20^{\mathrm{b}}$ & $93.53 \pm 2.89^{\mathrm{b}}$ & 16 \\
\hline 711 & $0.78 \pm 0.20^{\mathrm{a}}$ & $656.96 \pm 3.82^{\mathrm{a}}$ & $109.69 \pm 0.20^{\mathrm{a}}$ & $119.68 \pm 0.20^{\mathrm{a}}$ & 18 \\
\hline 821 & $0.80 \pm 0.15^{\mathrm{a}}$ & $640.15 \pm 2.57^{\mathrm{b}}$ & $79.92 \pm 0.20^{\mathrm{d}}$ & $89.91 \pm 0.20^{c}$ & 20 \\
\hline 100 & $0.76 \pm 0.00^{a}$ & $87.97 \pm 0.00^{c}$ & $65.96 \pm 0.46^{\mathrm{e}}$ & $59.22 \pm 0.15^{\mathrm{c}}$ & 8 \\
\hline
\end{tabular}

There was significant difference $(\mathrm{P}<0.05)$ in only sample code 100 which is $100 \%$ wheat sample in the water absorption capacity of the samples studied. The highest WAC of the composite flour could be ascribed to the presence of amount of carbohydrates (starch) and fibre in sample flour. Water absorption capacity is a vital function of protein in various food products like soups, dough and baked products [32]. The results showed increase in WAC with increase in defatted soybean flour inclusion. This may be connected to soybean fiber hygroscopic properties, thus, on exposure to moisture it swells [33]. Similar values were obtained from Mbaeyi [22] for treated and untreated sorghum and pigeon pea breakfast cereals.

A gel represents a transitional phase between solid and liquid states. In food systems, the solid consists of proteins, polysaccharides or a mixture of both, while the liquid is usually water. The gelation properties can be influenced by the ionic strength, $\mathrm{pH}$ and the presence of non-protein components as reported by Sridaran, et al. [34]. Sample 821 (Soy-groundnut at ratio 10:30) formed a gel at a significantly higher concentration (20 g/ 100 $\mathrm{ml}$ ). Sample 100 (wheat flour) formed gel quickly at very lowest concentration $(8 \mathrm{~g} / 100 \mathrm{ml})$. The gradual reduction in the gelation capacity with decreasing defatted soybean ratio may be as a result of high fiber content with high water absorption capacity and thus does not thicken or gel on heating [33]. Sample 711 recorded the highest value (119.68\%) and lowest value (59.22) with sample 100

\subsection{Mineral Analysis}

The results of the mineral composition of flakes as shown in Table 4, the sodium (Na) values of the formulated flakes blends ranged between 19.97-25.65PPM. Sample 425 has the highest sodium value while sample 821 has the lowest value. Also, the value of defatted soybean in the flakes is directly proportional to the amount of sodium in the blends. All the values were significantly different $(\mathrm{P}<0.05)$. Although sodium helps in maintaining the water balance in the body, absorption and transmission of some nutrients and nerve impulses. Health practitioners have encouraged reduction in the intake of sodium because it has been found out to increase the rate of blood pressure in salt sensitive individuals. The potassium $(\mathrm{K})$ content of flakes samples was relatively high than other minerals analyzed. The value range from 52.78-84.43PPM. sample 711 had the highest value of $K$ content while sample 425 has the lowest value. Due to the fact that moringa is rich in potassium [35] it can be inferred that moringa contributed more to the potassium content of the formulated samples. All the values were significantly different $(\mathrm{P}<0.05)$.

The calcium (Ca) content of the flakes sample range from 15.44 - 26.39PPM. Sample 425 had the highest calcium value while sample 821 had the lowest value. Calcium is vital in maintaining total body health and it also help both the bones and teeth to be strong. It ascertains proper performance of muscles and nerves. The results indicate that high amount of defatted soybean yields high calcium value of the flakes. Sample 522 and 711 , sample 821 and 100 values were not significantly different $(\mathrm{P}<0.05)$, only sample 425 was significantly different $(\mathrm{P}<0.05)$. 
Table-4. Mineral analysis of flakes prepared from blend samples.

\begin{tabular}{|c|c|c|c|c|c|}
\hline Samples & $\operatorname{Sodium}(\mathrm{g} / \mathrm{ml})$ & $\operatorname{Potassium}(\mathrm{g} / \mathrm{ml})$ & $\operatorname{Calcium}(\mathrm{g} / \mathrm{ml})$ & $\operatorname{Iron}(\mathrm{g} / \mathrm{ml})$ & Phosphorus(g/ml) \\
\hline 425 & $25.65 \pm 0.70^{\mathrm{b}}$ & $52.78 \pm 0.12^{\mathrm{d}}$ & $26.39 \pm 0.02^{b}$ & $1.46 \pm 0.07^{\mathrm{a}}$ & $19.79 \pm 0.01^{\mathrm{a}}$ \\
\hline 522 & $22.42 \pm 0.18^{\mathrm{a}}$ & $63.100 \pm 0.00^{c}$ & $23.43 \pm 0.28^{\mathrm{a}}$ & $0.30 \pm 0.02^{b}$ & $14.66 \pm 0.03^{c}$ \\
\hline 711 & $21.76 \pm 0.08^{\mathrm{d}}$ & $84.43 \pm 0.80^{\mathrm{a}}$ & $20.66 \pm 0.64^{a}$ & $0.17 \pm 0.14^{c}$ & $10.95 \pm 0.01^{\mathrm{d}}$ \\
\hline 821 & $19.97 \pm 0.09^{\mathrm{c}}$ & $70.50 \pm 0.14^{\mathrm{c}}$ & $15.44 \pm 0.04^{\mathrm{c}}$ & $0.07 \pm 0.00^{\mathrm{d}}$ & $17.26 \pm 0.02^{\mathrm{b}}$ \\
\hline
\end{tabular}

The iron ( $\mathrm{Fe}$ ) content of the Flakes range from 0.07 - 1.46 PPM. Sample 425 had the highest iron content while sample 821 had the lowest value. From the results, it indicates that defatted soybean contribute to the iron content in the flakes. The content of calcium and iron of the composite flour 425 shows that products from the flour would be nutritionally beneficial for children for strong bone, blood formation and body development. The mineral content of flakes obtained in this study is in agreement with the values reported by Oboh [36] for wheat-sunflower barley cookies.

\subsection{Antioxidants}

The result of antioxidant properties of flakes from the composite blends is presented in Table 5 . The flavonoids content value range from $1.50-1.68 \mathrm{~g} / \mathrm{mg}$. There is no significant difference $(\mathrm{P}<0.05)$ between the samples. from the results, it was observed that the samples with highest flavonoid had a flour combination of $20 \%$ soybean and $20 \%$ groundnut, which implies that both the soybean and groundnut contribute to the flavonoid content. The TPC values reported varied among the different composite

Table-5. Antioxidant analysis of flakes from a blend samples.

\begin{tabular}{|c|c|c|c|}
\hline Flakes & Phenol(mg/g) & Flavonoids(mg/g) & Ascorbic acid (mg/g) \\
\hline 425 & $2.59 \pm 0.23^{a b}$ & $1.50 \pm 0.06$ & $30.86 \pm 0.68^{\mathrm{b}}$ \\
\hline 522 & $2.62 \pm 0.52^{\mathrm{ab}}$ & $1.70 \pm 0.20^{\mathrm{ab}}$ & $25.30 \pm 2.60^{\mathrm{c}}$ \\
\hline 711 & $2.74 \pm 0.37^{\mathrm{ab}}$ & $1.81 \pm 0.06^{\mathrm{a}}$ & $21.38 \pm 0.37^{\mathrm{d}}$ \\
\hline 821 & $3.03 \pm 0.08^{a}$ & $1.68 \pm 0.08^{\mathrm{ab}}$ & $20.05 \pm 1.03^{\mathrm{a}}$ \\
\hline
\end{tabular}
significantly different $(\mathrm{p}<0.05)$.

Flour containing flakes as shown in Table 5. The phenol content of the composite flour range from 2.59 $3.03 \mathrm{~g} / \mathrm{mg}$. There were no significant different between all the samples. The highest value is found in sample 821 (10\% soybean: $30 \%$ groundnut) while the lowest value is found in sample 425 (30\% soybean: $10 \%$ groundnut). Groundnut had a contribution in phenolic content of the flour. Total phenolic compounds TPC were quantified by the Folin-Ciocalteu method which is an electron transfer based assay and measures reducing capacity. Phenol phytochemicals inhibit auto oxidation of unsaturated lipids, thus preventing the formation of oxidized low-density lipoprotein (LDL) which is considered to induce cardiovascular disease [37]. These values were generally higher than those reported by Kaushal, et al. [37] on some tropical cereals and legumes. The vitamin $\mathrm{C}$ content ranged from $20.05 \mathrm{mg} / 100 \mathrm{~g}$ to $30.86 \mathrm{mg} / 100 \mathrm{~g}$. sample 425 had the highest value while sample 821 had the lowest value. It was observed that the value of vitamin $\mathrm{C}$ decrease with decrease in defatted soybean and increased in defatted groundnut. It can be due to the soybeans in the composite flour which contribute to the vitamin content of the flakes. Ascorbic acid plays a key nutritional role in foods. It is an essential nutrient for human, a deficiency of which causes scury. It is also a potent antioxidant, protecting the body from oxidative stress. 


\subsection{Sensory Analysis}

The sensory evaluation results performed on different flakes produced are shown in Table 6 panelist rated the flakes prepared from $100 \%$ wheat flour as the best in terms of appearance, taste, aroma and overall acceptability. Sample 100 (100\% wheat) scaled like moderately with respect to aroma (7.52), followed by sample 711 (6.45), 425 (5.90), 821 (5.10) and 522 (4.75). From the results, the three most preferred product after control (711, 425 and 821$)$ and the least preferred in term of aroma is sample 522 which had high defatted soybean and low defatted groundnut content. The sensory analysis in term of appearance, texture, taste and overall acceptability, sample $100(100 \%$ wheat) which was the control had the best value followed by sample 711 (6.45\%) with a balanced ratio of defatted soybean and defatted groundnut (20:20\%) then followed by sample 425 (5.90\%) ratio 30:10, sample 821 (5.10) containing $10 \%$ defatted soybean with $30 \%$ defatted groundnut, followed by the least acceptable sample 522 $(4.75 \%)$.

Table-6. Sensory analysis of flakes from blend samples.

\begin{tabular}{cccccc}
\hline Samples & Aroma & Appearance & Texture & Taste & Acceptability \\
\hline 425 & $5.90 \pm 1.07^{\mathrm{ab}}$ & $5.35 \pm 1.57^{\mathrm{b}}$ & $6.40 \pm 1.14^{\mathrm{a}}$ & $5.85 \pm 1.53^{\mathrm{a}}$ & $6.10 \pm 1.52^{\mathrm{a}}$ \\
522 & $4.75 \pm 1.52^{\mathrm{c}}$ & $3.70 \pm 1.42^{\mathrm{c}}$ & $5.30 \pm 1.49^{\mathrm{b}}$ & $5.10 \pm 1.21^{\mathrm{b}}$ & $5.05 \pm 1.15^{\mathrm{b}}$ \\
711 & $6.45 \pm 1.50^{\mathrm{a}}$ & $6.40 \pm 1.50^{\mathrm{d}}$ & $6.70 \pm 1.26^{\mathrm{a}}$ & $6.40 \pm 1.31^{\mathrm{ab}}$ & $6.60^{\mathrm{b}} \pm 1.27^{\mathrm{a}}$ \\
821 & $5.10 \pm 1.37^{\mathrm{bc}}$ & $6.20 \pm 1.28^{\mathrm{ab}}$ & $6.10 \pm 0.85^{\mathrm{a}}$ & $5.30 \pm 1.69^{\mathrm{b}}$ & $5.85 \pm 1.42^{\mathrm{ab}}$ \\
100 & $7.52 \pm 1.05^{\mathrm{d}}$ & $7.53 \pm 0.04^{\mathrm{a}}$ & $7.44 \pm 1.19^{\mathrm{e}}$ & $7.40 \pm 0.91^{\mathrm{c}}$ & $7.52 \pm 1.05^{\mathrm{a}}$ \\
\hline Note: Values are means + SD of triplicate determinations Means differently superscripted along the vertical columns are significantly different $(\mathrm{p}<0.05)$.
\end{tabular}

\section{CONCLUSION}

In conclusion, using an extruder to be able to produce flakes of an improved protein and anti-oxidant is excellent. With this, it can be established that the use of local cereal base for the production of flakes is possible and good when using extrusion process and provides a good quality when supplement maize with soybean and groundnut. Based on the chemical composition of the flakes, blending of cereals and legumes cause a significant increase in protein content and carbohydrate content making it a suitable ingredient for malnutrition diets. With respect to the nutritional composition, the addition of moringa seed to the blend samples increased the potassium, calcium, iron and phosphorus content of the flakes, this makes the blends better source of micronutrients. Also, the incorporating of moringa seed increased the total phenolic compound, vitamin $\mathrm{C}$ and flavonoids content. The samples from composite flour had the ability to withstand cracking strength compare to $100 \%$ wheat flour.

\section{REFERENCES}

[1] P. G. Williams, "The benefits of breakfast cereal consumption: A systematic review of the evidence base," Advances in Nutrition, vol. 5, pp. 636S-673S, 2014.Available at: https://doi.org/10.3945/an.1 14.006247.

[2] P. J. Kanu, E. H. Sandy, B. J. Kandeh, J. Z. Bahsoon, and Z. Huiming, "Production and evaluation of breakfast cerealbased porridge mixed with sesame and pigeon peas for adults," Pakistan Journal of Nutrition, vol. 8, pp. 1335-1343, 2009.Available at: https://doi.org/10.3923/pjn.2009.1335.1343.

[3] P. J. Kanu, Z. Kerui, Z. H. Ming, Q. Haifeng, J. B. Kanu, and Z. Kexue, "Sesame protein 11: Functional properties of sesame (Sesamum indicum L.) protein isolate as influenced by $\mathrm{pH}$, temperature, time and ratio of flour to water during its production," Asian Journal of Biochemistry, vol. 2, pp. 289-301, 2007.Available at: https://doi.org/10.3923/ajb.2007.289.301. 
[4] F. Anwar, S. Latif, M. Ashraf, and A. H. Gilani, "Moringa oleifera: A food plant with multiple medicinal uses," Phytotherapy Research: An International Journal Devoted to Pharmacological and Toxicological Evaluation of Natural Product Derivatives, vol. 21, pp. 17-25, 2007.

[5] L. Gopalakrishnan, K. Doriya, and D. S. Kumar, "Moringa oleifera: A review on nutritive importance and its medicinal application," Food Science and Human Wellness, vol. 5, pp. 49-56, 2016.Available at: https://doi.org/10.1016/j.fshw.2016.04.001.

[6] J. Onweluzo and O. Nnamuchi, "Production and evaluation of porridge-type breakfast product from Treculia africana and sorghum bicolor flours," Pakistan Journal of Nutrition, vol. 8, pp. 731-736, 2009.Available at: https://doi.org/10.3923/pjn.2009.731.736.

[7] G. Okafor and G. Usman, "Physical and functional properties of breakfast cereals from blends of maize, African yam bean, defatted coconut cake and sorghum extract," Food Science and Quality Management, vol. 40, pp. 25-34, 2015.

[8] Y. Maphosa and V. A. Jideani, "The role of legumes in human nutrition," In Functional Food-Improve Health through Adequate Food 2017 Aug 2. IntechOpen, 2017.

[9] C. Rebello, F. Greenway, and J. W. Finley, "A review of the nutritional value of legumes and their effects on obesity and its related co-morbidities," Obesity Reviews, vol. 15, pp. 392-407, 2014.Available at: https://doi.org/10.1111/obr.12144.

[10] G. A. Annor, M. Zhen, and J. I. Boye, Crops-legumes. In: Clark S, Jung S, Lamsal B, editors. Food processing: Principles and applications. Chichester: John Wiley \& Sons, Ltd, 2014.

[11] M. Bouchenak and M. Lamri-Senhadji, "Nutritional quality of legumes, and their role in cardiometabolic risk prevention: A review," Journal of Medicinal Food, vol. 16, pp. 185-198, 2013.Available at: https://doi.org/10.1089/jmf.2011.0238.

[12] H. Jaenicke and N. Pasiecznik, "Making the most of underutilised crops," Leisa, vol. 25, pp. 11-12, 2009.

[13] J. Ndife, L. Abdulraheem, and U. Zakari, "Evaluation of the nutritional and sensory quality of functional breads produced from whole wheat and soya bean flour blends," African Journal of Food Science, vol. 5, pp. 466-472, 2011.

[14] AOAC, Official methods of analysis, 18th ed. Washington D.C, USA: Association of Official Analytical Chemists, 2010.

[15] A. B. Boham and D. C. Kocipai, "Flavonoid and condensed tannins from leaves of Hawaiian Vaccininum vaticulum and vicalycilum," Pacific Science, vol. 48, pp. 458 - 463, 1994.

[16] L. Fu, "Antioxidant activities and total phenolic contents of fruits, herbal teas, tea drinks and wild fruits," Master Dissertation, Sun Yat-Sen University, Guangdong Province, China, 2010.

[17] G. I. Onwuka, Food analysis and instrumentation: Theory and practice. Lagos: Naphthali Prints, 2005.

[18] S. Sanni, A. Adebowale, I. Olayiwola, and B. Maziya-Dixon, "Chemical composition and pasting properties of Iron fortified maize flour," Journal of Food, Agriculture and Environment, vol. 6, pp. 172-175, 2008.

[19] C. Coffmann and V. Garciaj, "Functional properties and amino acid content of a protein isolate from mung bean flour," International Journal of Food Science \& Technology, vol. 12, pp. 473-484, 1977.Available at: https://doi.org/10.1111/j.1365-2621.1977.tbo0132.x.

[20] R. Adeleke and J. Odedeji, "Functional properties of wheat and sweet potato flour blends," Pakistan Journal of Nutrition, vol. 9, pp. 535-538, 2010.Available at: https://doi.org/10.3923/pjn.2010.535.538.

[21] S. Agunbiade and M. Ojezele, "Quality evaluation of instant breakfast meals fabricated from maize, sorghum soybean and yam bean (Sphenostylis stenocarpa)," World Journal of Dairy \& Food Sciences, vol. 5, pp. 67-72, 2010.

[22] I. E. Mbaeyi, "Production and evaluation of breakfast cereals using pigeon-pea (Cajanus cajan) and sorghum (Sorghum bicolor L.)," M.Sc. Thesis Department of Food Science and Technology, University of Nigeria, Nsukka, 2005. 
[23] D. A. Knauft and P. Ozias-Akins, Recent methodologies for germplasm enhance-ment and breeding. In: H. E. Pattee and H. T. Stalker (Eds.), Advances inpeanut science. Stillwater, OK: Am. Peanut Res. Educ. Soc, 1995.

[24] S. Ukachukwu and F. Obioha, "Effect of time duration of thermal treatments on the nutritive value of Mucuna Chochinchinensis," Global Journal of Pure and Applied Sciences, vol. 6, pp. 11-16, 2000.Available at: https://doi.org/10.4314/gjpas.v6i1.16096.

[25] A. I. Ihekoronye and P. O. Ngoddy, Integrated food science and technology for the topics. New York: Macmillan Publishers, 1985.

[26] I. Bolarinwa, S. Olaniyan, L. Adebayo, and A. Ademola, "Malted sorghum-Soy composite flour: Preparation, chemical and physico-chemical properties," Journal of Food Processing Technology, vol. 6, pp. 1-7, 2015.Available at: https://doi.org/10.4172/2157-7110.1000467.

[27] T. P. Trinidad, A. C. Mallillin, D. H. Valdez, A. S. Loyola, F. C. Askali-Mercado, J. C. Castillo, R. R. Encabo, D. B. Masa, A. S. Maglaya, and M. T. Chua, "Dietary fiber from coconut flour: A functional food," Innovative Food Science $\bigotimes^{\circ}$ Emerging Technologies, vol. 7, pp. 309-317, 2006.Available at: https://doi.org/10.1016/j.ifset.2004.04.003.

[28] B. McKevith, "Nutritional aspects of cereals final report to the home grown cereal authority," Nutrition Scientist, British Nutrition Foundation, pp. 126-213, 2004.

[29] Weetabix, "Nutrition Facts for Cereals ready-to eat, Weetabix whole wheat cereal weetabix ltd." Retrieved from: www.nal.usda.gov/frinc/foodcomp. [Accessed Sept, 2010], 2010.

[30] M. Iwe and O. Onalope, "Effect of extruded full-fat soy flour into sweet potato flour on functional properties of the mixture," Journal of Environment ङ Sustainable Agriculture, vol. 3, pp. 109-1 17, 2001.

[31] S. Achinewhu, L. Barber, and I. Ijeoma, "Physicochemical properties and garification (gari yield) of selected cassava cultivars in Rivers State, Nigeria," Plant Foods for Human Nutrition, vol. 52, pp. 133-140, 1998.

[32] E. I. Adeyeye and P. A. Aye, "Chemical composition and the effect of salts on the food properties of wheat flour," Pakistan Journal of Nutrition, vol. 4, pp. 187-196, 2005.

[33] R. Wasserman, "Properties of coconut fiber." Retrieved from: http://www.livestrong.com/article/249254-propertiesof-coconut-fiber/. [Accessed 19/8/10], 2010.

[34] A. Sridaran, A. A. Karim, and R. Bhat, "Pithecellobium jiringa legume flour for potential food applications: Studies on their physico-chemical and functional properties," Food Chemistry, vol. 130, pp. 528-535, 2012.Available at: https://doi.org/10.1016/j.foodchem.2011.07.062.

[35] B. Skrbić and J. Cvejanov, "The enrichment of wheat cookies with high-oleic sunflower seed and hull-less barley flour: Impact on nutritional composition, content of heavy elements and physical properties," Food Chemistry, vol. 124, pp. 1416-1422, 2011.Available at: https://doi.org/10.1016/j.foodchem.2010.07.101.

[36] G. Oboh, "Hepatoprotective property of ethanolic and aqueous extracts of Telfairia occidentalis (fluted pumpkin) leaves against garlic-induced oxidative stress," Journal of Medicinal Food, vol. 8, pp. 560-563, 2005.

[37] P. Kaushal, V. Kumar, and H. Sharma, "Comparative study of physicochemical, functional, antinutritional and pasting properties of taro (Colocasia esculenta), rice (Oryza sativa) flour, pigeonpea (Cajanus cajan) flour and their blends," LWT-Food Science and Technology, vol. 48, pp. 59-68, 2012.Available at: https://doi.org/10.1016/j.lwt.2012.02.028. 